UDC 347.122

LBC 67.404.0

\title{
COMPARATIVE ANALYSIS OF OBJECTS OF CIVIL RIGHTS AND OBJECTS OF CIVIL LAW RELATIONS
}

\author{
Antonina V. Goncharova \\ Volgograd Institute of Humanities, Volgograd, Russian Federation
}

\begin{abstract}
Introduction. A comparative analysis of the concepts of "object of civil rights" and "the object of civil relations" are considered in this article. The relevance of the research is determined by several factors. Firstly, the legislation defines neither objects of civil rights, nor objects of civil law relations. Secondly, the scientific definition of the object of civil rights and the object of civil relations is a major problem in the theory of civil law, and perhaps one of the most controversial issues. The purpose of the study is to conduct a theoretical analysis as an object of civil rights, as well as the object of civil relations. Taking this into account, the objectives of the study are the following: a comprehensive study of the concept of "object of civil rights" and "the object of civil relations"; the definition of "object of civil rights" and "the object of civil relations." This theme draws attention of a wide range of researchers. However, in the majority of works devoted to the objects of civil rights, there is no consensus on the concept of the object of civil rights, and the object of civil relations. Some authors distinguish between the concept of the object of civil rights and the object of civil legal relationship. Conclusion. Analyzing the point of view of lawyer on the concept of the object of civil rights and the object of civil relations, the author made the conclusion that it is identical to the concept, and given its scientific definition of "object of civil rights".
\end{abstract}

Key words: object of civil rights, object of civil relations, comparative analysis of objects, civil law, civilists.

УДК 347.122

ББК 67.404 .0

\section{СРАВНИТЕЛЬНЫЙ АНАЛИЗ ОБЪЕКТОВ ГРАЖДАНСКИХ ПРАВ И ОБЪЕКТОВ ГРАЖДАНСКИХ ПРАВООТНОШЕНИЙ}

\author{
Антонина Викторовна Гончарова \\ Волгоградский гуманитарный институт, г. Волгоград, Российская Федерация
}

\begin{abstract}
Введение: в настоящей статье рассматривается сравнительный анализ понятий «объект гражданских прав» и «объект гражданских правоотношений». Актуальность проведения научного исследования определяется рядом факторов. Во-первых, законодательство не дает определения ни объектам гражданских прав, ни объектам гражданских правоотношений. Во-вторых, научное определение объекта гражданских прав и объекта гражданских правоотношений является крупной проблемой в теории гражданского права и едва ли не одним из самых дискуссионных вопросов. Цель исследования состоит в проведении теоретического анализа как объекта гражданских прав, так и объекта гражданских правоотношений. Учитывая это, задачами исследования выступают: всестороннее изучение и определение понятий «объект гражданских прав» и «объект гражданских правоотношений». Данная тема привлекает внимание широкого круга уче๓ं ных. Тем не менее в большинстве работ, посвященных объектам гражданских прав и объектам гражданс¿ ких правоотношений, нет единого мнения по вопросам соответствующих понятий. Некоторые авторы \%ิ различают понятия объекта гражданских прав и объекта гражданского правоотношения. Вывод: проанало. лизировав точки зрения цивилистов по вопросам о понятиях объекта гражданских прав, объекта гражданఫ्ञ ских правоотношений, сделан вывод о том, что это идентичные понятия, и дано свое научное определение () объекту гражданских прав.
\end{abstract}


Ключевые слова: объект гражданских прав, объект гражданских правоотношений, сравнительный анализ объектов, гражданское право, цивилисты.

\section{Введение}

В цивилистической литературе нет единого мнения по вопросам понятий объекта гражданских прав, объекта гражданских правоотношений. Данные проблемы являются достаточно сложными в науке гражданского права. Здесь трудно найти положение, которое всеми бы единодушно признавалось и не вызывало споров.

Гражданский кодекс Российской Федерации не дает определения объекта гражданских прав и объекта гражданских правоотношений. Что касается объектов гражданских прав, то он пошел по пути перечисления отдельных видов (ст. 128 ГК РФ) [1]. Исходя из данного перечня автор формулирует понятие объекта гражданских прав.

Стоит поддержать господствующую в гражданском праве теорию о том, что объект гражданских прав и объект гражданских правоотношений - это тождественные понятия. Сторонниками данной позиции выступают А.П. Сергеев [2, с. 205], Н.Д. Егоров [3, с. 80], А.О. Иншакова [6, с. 21-22] и др.

\section{Различие и сходство понятий «объект гражданских прав»}

\section{и «объект гражданского правоотношения»}

Научное определение объекта гражданских прав и объекта гражданских правоотношений является крупной проблемой в теории гражданского права и едва ли не одним из самых дискуссионных вопросов. Проанализировав точки зрения цивилистов по вопросам о понятиях объекта гражданских прав и объекта гражданских правоотношений, можно сделать вывод о том, что все они делятся на четыре группы.

К представителям первой группы мы можем отнести О.Н. Садикова, О.С. Иоффе, М.М. Агаркова и др. Так, О.Н. Садиков определяет объект гражданских прав как то, на что направлены права и обязанности субъектов гражданских правоотношений [5, с. 260]. O.C. Иоффе рассматривает объект как то, на что направлены, а точнее воздействуют, граж- данское субъективное право и гражданскоправовая обязанность [7, с. 82]. Российскому гражданскому праву свойственно двухчленовое разделение объектов на вещи и чужие действия. Оба эти предмета подпадают под понятие имущества. Следовательно, можно сказать, что имущество является объектом гражданских прав.

Представители второй группы рассматривают в качестве объекта права поведение людей. Так, Ю.К. Толстой, А.П. Сергеев указывают, что в качестве объекта гражданского правоотношения выступает поведение его субъектов, направленное на различного рода материальные и нематериальные блага [3, c. 80]. Я.М. Магазинер определяет объект гражданского правоотношения как поведение граждан и юридических лиц [10, с. 66].

Анализируя данную позицию авторов, можно сделать следующие выводы. Во-первых, данная позиция не соответствует легальному перечню объектов гражданских прав, закрепленных в ст. 28 ГК РФ, где к объектам гражданских прав относятся и вещи, и имущество, и работы, и услуги... Следовательно, в соответствии с законодательной трактовкой объектом выступает не только поведение людей, но и то, по поводу чего это поведение складывается. Во-вторых, приведенные определения не совпадают с понятием объекта с позиции философии, где объект - это то, что противостоит субъекту, на что направлена его практическая и познавательная деятельность [11]. Поэтому, на наш взгляд, определять объект как поведение субъектов не вполне верно.

Представители третьей группы ставят в угол определения объекта гражданских прав гражданское правоотношение. Так, М.И. Брагинский указывает, что объектом гражданских прав признается то, по поводу чего возникает гражданское правоотношение [9, с. 172]. Сходное определение дают и авторы Комментария к Гражданскому кодексу РФ под редакцией Т.Е. Абовой и А.Ю. Кабалкина: «Под объектами гражданского правоотношения понимается то, на что они направлены, по поводу чего они возникают и существуют» $[8$, с. 300$]$. 
Сравнивая приведенные определения, можно констатировать, что, несмотря на кажущуюся их близость, они имеют существенное различие. Так, представители второй группы, в частности М.И. Брагинский, более широко трактуют понятие объекта. В соответствии с общей теорией права в состав правоотношения входят объект, субъект, субъективные права и юридические обязанности [9]. Следовательно, давая понятие объекта через гражданское правоотношение, М.И. Брагинский фактически склоняется к определению объекта через объект, так как само понятие объекта уже входит в состав правоотношения. Заменяя в определении М.И. Брагинского «гражданское правоотношение» его составом, можно получить следующее определение: «объектом гражданских прав признается то, по поводу чего возникают объект, субъект, субъективные права и юридические обязанности».

\section{Выводы}

Таким образом, можно смело утверждать, что такие понятия, как объект гражданских прав и объект гражданских правоотношений, тождественны. Учитывая приведенные выше точки зрения, а также основывая свою позицию на легальном перечне объектов гражданских прав, сформулированном в ст. 128 ГК РФ, и поддерживая господствующую в гражданском праве теорию о том, что объект гражданских прав и объект гражданских правоотношений это тождественные понятия, предлагается следующее определение объекта гражданских прав: это материальные и нематериальные блага, по поводу которых возникают субъективные гражданские права и гражданско-правовые обязанности субъектов права.

\section{СПИСОК ЛИТЕРАТУРЫ}

1. Гражданский кодекс Российской Федерации. Ч. 1 // Собрание законодательства РФ. - 1994. № 32. - Ст. 3301; 1996. - № 5. - Ст. 409.

2. Гражданское право. В 3 ч. Ч. 1 / под ред. А. П. Сергеева, Ю. К. Толстого. -Изд. 3, перераб. и доп. - М. : Проспект, 1998. - 632 с.
3. Гражданское право. В 3 ч. Ч. 2 / под ред. А. П. Сергеева, Ю. К. Толстого. - Изд. 3, перераб. и доп. - М. : Проспект, 1998. - 784 с.

4. Гражданское право. В 2 т. Т. 1 / под ред. Е. А. Суханова. - 2-е изд., перераб. и доп. - М. : БЕК, 1998. $-816 \mathrm{c}$.

5. Гражданское право России. Общая часть / под ред. О. Н. Садикова. - М. : Юристь, 2001. - 776 с.

6. Иншакова, А. О. Формы защиты интеллектуальной собственности в обновленном гражданском законодательстве РФ / А. О. Иншакова // Власть закона. -2015. - № 2. - С. 19-31.

7. Иоффе, О. С. Правоотношение по советскому гражданскому праву / О. С. Иоффе. - Л. : Изд-во Ленинградского университета, 1949. - 143 c.

8. Комментарий к Гражданскому кодексу РФ. В 2 т. Т. 1 / под ред. Т. Е. Абовой, А. Ю. Кабалкина. М. : Юрайт-Издат : Право и закон, 2002. - 880 с.

9. Комментарий к части первой Гражданского кодекса Российской Федерации для предпринимателей / под ред. М. И. Брагинского. - М. : Правовая культура : Хозяйство и право, 1995. - 479 с.

10. Магазинер, Я. М. Объект права / Я. М. Магазинер // Очерки по гражданскому праву : сб. ст. Л.: Изд-во Ленинградского университета, 1957. C. $65-78$.

11. Современная энциклопедия. - Электрон. текстовые дан. - Режим доступа: http://www.dic. academic.ru. - Загл. с экрана.

\section{REFERENCES}

1. Grazhdanskiy kodeks Rossiyskoy Federatsii. Ch. 1. [The Civil Code of the Russian Federation. Part 1]. Sobranie zakonodatelstva Rossiyskoy Federatsii, 1994, no. 32, art. 3301; 1996, no. 5, art. 409.

2. Sergeev A.P., Tolstoy Yu.K., eds. Grazhdanskoe pravo. Uchebnik. Chast I [Civil Law. Textbook. Part I]. Moscow, Prospekt Publ., 1998. 632 p.

3. Sergeev A.P., Tolstoy Yu.K., eds. Grazhdanskoe pravo. Uchebnik. Chast II [Civil Law. Textbook. Part II]. Moscow, Prospekt Publ., 1998. $784 \mathrm{p}$.

4. Grazhdanskoe pravo. T. I [Civil Law.Vol. I]. Moscow, BEK Publ., 1998. 816 p.

5. Sadikov O.N., ed. Grazhdanskoe pravo Rossii. Obshchaya chast. Kurs lektsiy [Civil Law of Russia. Common Part. Course of Lectures]. Moscow, Yurist Publ., 2001. 776 p.

6. Inshakova A.O. Formy zashchity intellektualnoy sobstvennosti v obnovlennom grazhdanskom zakonodatelstve RF [The Forms of Intellectual Property Protection in a Renewed Civil Legislation of the Russian Federation]. Vlast zakona, 2015, no. 2, pp. 19-31. 
7. Ioffe O.S. Pravootnoshenie po sovetskomu grazhdanskomu pravu [Legal Relations in the Soviet Civil Law]. Leningrad, $1949.143 \mathrm{p}$.

8. Abova T.E., Kabalkin A.Yu. Kommentariy $k$ Grazhdanskomu kodeksu RF. Ch. 1 [Comment to the Civil Code of the Russian Federation. Part one]. Moscow, Yurayt-Izdat Publ., 2002. 880 p.

9. Braginskiy M.I. Kommentariy k chasti pervoy Grazhdanskogo Kodeksa Rossiyskoy Federatsii dlya predprinimateley [Commentary on the First Part of the Civil Code of the Russian Federation for Entrepreneurs]. Moscow, Pravovaya kultura Publ., $1995.479 \mathrm{p}$.

10. Magaziner Ya.M. Obyekt prava. Ocherki po grazhdanskomu pravu [Property Rights. Essays on the Civil Law]. Leningrad, 1957, pp. 65-78.

11. Sovremennaya entsiklopediya [Modern Encyclopedia]. Available at: dic.academic.ru.

\section{Information About the Author}

Antonina V. Goncharova, Candidate of Juridical Sciences, Associate Professor, Dean of Law Faculty, Volgograd Institute of Humanities, Gribanova St., 12, 400119 Volgograd, Russian Federation, AntoninaVS@mail.ru.

\section{Информация об авторе}

Антонина Викторовна Гончарова, кандидат юридических наук, доцент, декан юридического факультета, Волгоградский гуманитарный институт, ул. Грибанова, 12, 400119 г. Волгоград, Российская Федерация, AntoninaVS@mail.ru. 